\title{
Incomegetting and Environmental Degradation
}

\author{
Ossi I. Ollinaho ${ }^{1, *(\mathbb{D})}$ and V. P. J. Arponen ${ }^{2}$ (D) \\ 1 Faculty of Social Sciences, University of Helsinki, 00014 Helsinki, Finland \\ 2 ROOTS Cluster of Excellence, Kiel University, Leibnizstrasse 3, 24118 Kiel, Germany ; \\ varponen@gshdl.uni-kiel.de \\ * Correspondence: ossi.ollinaho@helsinki.fi
}

Received: 3 April 2020; Accepted: 12 May 2020; Published: 14 May 2020

\begin{abstract}
Drawing on Alfred Schütz's thought, as well as on a number of modern pragmatists and practice theorists, we theorize incomegetting - referring to practices of getting income, typically salaried work - as the paramount structurer of everyday life and, therefore, also the chief mediator of the human-nature metabolism. Even though the pragmatics of everyday life as an aggregate underlie the bulk of environmental impacts, these insidious impacts impose little immediate influence on everyday life, in particular in the urban Global North. In other words, the pragmatic dimension of everyday activities-principally, work-that takes place within a vastly complex and globally interlinked productive world system, has most often no immediate connection to the "natural" environment. While parts of the populations are directly dependent in terms of livelihoods on the "natural" environment, these populations are typically pushed to the margins of the global productive system. The understanding formulated in this essay suggests that in environmental social sciences there is a reason to shift the epicenter of the analysis from consumption to everyday life, to the varied practices of incomegetting. Against the backdrop of this paper, universal basic income schemes ought to have radical impacts on the way we relate also to the "natural" environment and such schemes necessitate understanding the essence of money in our contemporary realities.
\end{abstract}

Keywords: incomegetting; work; life-world; environmental change; relevance; cumulative socio-material change; universal basic income; money

\section{Introduction}

It is an increasingly undeniable and disturbing fact that human induced climate change, as well as various other extensive-scale environmental problems from ecosystem decline to species extinction, are not only real processes and taking place on planet Earth today, but that such massive processes are also accelerating [1]. Even though many would like it to, such a deepening predicament does not translate into a pragmatically and intrinsically relevant issue in the human life-world, particularly in the Global North - a task in which a single virus succeeded much better in just a couple of weeks. Indeed, the contrast between the spectacular reception of the coronavirus pandemic in the beginning of 2020 and the phlegmatic climate change emergency, could not be clearer. The contrast tells much about the way our social realities are constructed today-they are mediated by digital and other information mediums [2]. Solid media attention to a single issue and subsequent policy decisions may be enough to disrupt everyday life-even if only partially and temporarily. However, the deepening environmental predicament, as well as the current pandemic, have done little to challenge the major structures of everyday life. The reception of the coronavirus pandemic attests also to the fact that economic growth remains on the throne: the massive bail-out schemes-similar to those in the previous economic crisis [3] - aim to save "business as usual", instead of seizing the opportunity to pursue structural changes. 
In the environmental discussion, there is a widespread frustration, visible also in scholarly debate, that people do not act as they ought to act, but instead keep contributing to the deepening environmental predicament. It appears that also scholars often, and problematically so, adopt a sort of ideal theory stance [4] in which they "prescribe how individual human beings or groups should ideally act" [5] (p. 26) instead of studying "what really goes on in our social lives"—as Hartmut Rosa claims would be needed today in critical social theory [6] (p. 7). Ecological realism, as an exemplar of ideal theory, aims to constitute "a rough sketch to inform how humans should ideally act" [7] (p. 11).

We maintain that a more adequate approach, an essentially "nonideal" account of social activity [4,5], can be found in the work of the Austrian born social theorist Alfred Schütz (1899-1959), whose "pragmatic theory of the life-world" [8] is particularly useful in understanding relevances-what is relevant for people in everyday life $[9,10]$. We relate Schutz's work to other philosophies, in particular to Theodore Schatzki's practice theory, in an attempt to bring phenomenological insights into how activities of getting income structures contemporary life-worlds beyond those activities themselves, aiming to contribute to the environmental social theory that has begun to focus on work [11-14]. While Schutz [15] saw the "world of work" as the paramount of multiple realities that we can experience, we conceptualize incomegetting - the manifold practices of getting income-as the paramount structurer of the life-world that constitutes the conditions for other issues of life.

Getting income, typically waged work, seems to be (much) more relevant to practical reason than whatever impacts such activities may have on the "natural" environment-also at the political level in our "era where the primary demand of the electorate is 'jobs, jobs, jobs'" [16] (p. 277). There is a growing understanding in the literature that the "normal workings" of industrial societies [17] (p. 221) entail cumulative socio-material changes [10] and that the normal workings are chiefly mediated in particular life-worlds by work $[11,13,14]$. Since the dawn of the industrial revolution, waged work has been institutionalized and gained centrality as a chief dimension in the pragmatics of everyday life [11,17]. For this, it appears to be also the chief mediator, or the very origin of separation [13], between humans and their biophysical_-"natural" as well as "built" - environments. There seems to be a need to return to Karl Marx, who claimed that the metabolic interaction between the humans and society unfolds through labor [18]. Marx saw that labor serves as "a process between man and nature, a process by which man, through his own actions, mediates, regulates and controls the metabolism between himself and nature" ([19] cited in [11] pp. 651-652). More specifically with regard to waged work, the separation between humans' inorganic condition and their activity can be understood "only in the relation of wage labour to capital" ([20] cited in [13] p. 51).

Today, the everyday life of the bulk of the urban population and the majority of the world population at large, appears to be to a significant extent decoupled from the "natural" environment as the "natural" environment does not directly provide the subsistence to these populations-rather, the relationship is indirectly mediated by often global production and distribution chains. Since changes in the "natural" environment are not immanently experienced within the "technologically textured" modern life-worlds [21], the environmental predicament enters the life-world of most urban people merely as an intellectual issue-as Max Weber already wrote a century ago [22]. While the salient role of waged work is an age old focus of social sciences, it has only recently appeared in the main stage of environmental social scientific theorizing [11-14,23]. In this paper, we aim at a "nonideal" account of social activity [5] by combining phenomenological analysis of the life-word with historical analysis of the real social conditions- "what really goes on in our social lives" [6] (p. 7)—in order to clarify the conditions for radical transformation when facing deepening global environmental predicament.

Our purpose here is to justify the view in which incomegetting is the chief structurer of the contemporary life-worlds, which, we argue, is needed to understand the multiple predicament we are facing today. Our aims in this essay can be characterized as in a certain sense philosophical or conceptual, as opposed to, say, strictly empirical. Drawing from Schutz and practice theory, but also from a diverse range of other theoretical as well as practical literature, we aim to provide a conceptual framework for making conceptually explicit the multitude of issues that addressing 
our contemporary environmental predicament effectively is intrinsically tangled with. As such we hope that our occasionally critical remarks can nonetheless inspire and inform, both, theoretically as well as empirically interested audiences in their thinking about, and practical action aiming at, sustainable society.

With incomegetting we refer broadly to the source of livelihood or more exactly to getting money, that is, what people do in their daily life to make their money. This includes not only wage labor and credit, but also rent seeking [24], speculative as well as other investment activities, spanning from securing one's basic necessities to hoarding ever more wealth. While consumption is typically taken as the chief dimension through which humans impact the "natural" environment, we see that work has a much more pertinent role in this, as consumption presupposes income, or at least credit. Therefore, while Marx's theory of metabolism underscores the importance of "transforming the relationship between humans and nature so as to ensure a more sustainable social metabolism" [25], we see that this struggle ought to focus on the pivotal site that structures the life-worlds, that is, getting one's income.

If we want to understand the life-world in which people gear into their surrounding socio-materiality based on their subjective stocks of knowledge at hand, besides the mesh of practices [26], we have to understand history as part of which people acting within have had their consciousness—subjective stock of knowledge at hand-constituted. "Lifeworld combines", Don Ihde wrote, "both a genetic (historical) account and a structural one" [21] (p. 28). Therefore, in order to understand our current environmental predicament and the central role of incomegetting in that, we need to understand the actual historical social system, not just how people act in theory as a part of the mesh of social practices and material arrangements, as is often exclusively discussed, e.g., in Reference [27].

Below, we first discuss the decoupling between individual life-worlds and the "natural" environment. We then elaborate a view according to which situated pragmatic activity, in the typical case, has primacy over conscious thought. Third, we conceptualize materiality against such a backdrop as socio-materiality: pragmatic activity with others occurring in a material world as a part of and mediated by landscapes, infrastructures and technology. Fourth, we delineate some aspects of late modernity as a historical development as a part of which contemporary consciousness and relevances in terms of the environment-or indeed a lack of such relevances-are being constituted in the context of contemporary life-worlds. Finally, we conclude by discussing some implications of our argument on universal basic income schemes [28] and money.

\section{Decouplings}

Following others, e.g., References [27,29-31], we see human activity and values as intrinsically embedded in the social and material environment and explicate how this pragmatic sphere of everyday life is drastically decoupled from the environmental consequences of the capitalist acceleration [32]. Understanding such decoupling — which in certain cases approaches uncoupling —of the system and the life-world is already classically scrutinized in sociology, e.g., in References [33-35]. Often scholars view societies as intrinsically intertwined with their "natural" environments. For instance, Beck observed "an ongoing extension and deepening of combinations, confusions and "mixtures" of nature and society" [36] (p. 256). However, no matter how intertwined societies may be with their "natural" environments, such blending can be seen to take place at an aggregate level. At the individual level, modern life-worlds and livelihoods within it, are often well insulated-decoupled-from insidious changes in the "natural" environment. This radical decoupling is a systemic issue that has to be understood also in socio-ecological systems thinking that tends to see "that social and ecological system dynamics are essentially similar" [37] (p. 475).

Applying Schutz's treatment of the concept of Lebenswelt-the life-world-to the present environmental predicament, we can see that the "natural" environment and its insidious changes are often only loosely or not at all connected particularly to the urban life-world. The daily life in cities into which people gear is not the "natural" environment, but one dominated by humans and human-made 
"built" environment, increasingly void of "naturally" growing flora and fauna. However, the typical environmentalist - the natural scientific observer-"excludes persons with their personal life and all objects of culture which originate as such in practical human activity" [15] (p. 58). This is exactly that layer of the life-world — the social reality—"which the social sciences have to investigate" [15] (p. 58). This seems to be also the case in socio-ecological systems literature [37].

Environmental social sciences in general appears to shy away from explicitly addressing their assumptions with regard to individuals and most often assumes more or less rational or at least intellectually driven people [38]. This appears to be also the case in socio-ecological systems literature [39] that continues to emphasize the ecological or the social system level, such as institutions or societies [40]. While some scholars focus on human agency [40,41], there seems to be a need to elaborate the "social" [37]. Overall, we see that there is a mismatch between the assumptions of environmental sciences about humans and actual "relevances" [15] as real people encounter them in living their lives. This we see as one major reason scholars have been intellectually frustrated with the masses of people not having organized a "storming of the Bastille" [36] over our environmental predicament. Nonetheless, while there is all the reason to be frustrated by the environmental predicament, rather than prescribing how human beings ought to act [5], the point of departure, instead, ought to be the daily experiences of social actors $[10,15]$ and relevances within.

\section{Relevances}

The distinction between the moral and the pragmatic is key to understanding how people react to environmental changes. In other words, whereas different types of environmental changes enter ever more frequently to life-worlds through different medias and have gained centrality in different policy arenas, the actual biophysical environmental changes are not automatically translated to the pragmatics of everyday life [10], particularly in the Global North. The relevances of such changes per se are imposed upon our life-worlds, rather than being intrinsic to them, as they take place outside of the primary relevance of our everyday life [42]. Certainly, some of these changes are observable through mere human sensory equipment, but in the metropoles, they rarely harm the core of the life-worlds: livelihoods. In fact, the further the livelihoods are removed from the land and its soil, the less changes in the biosphere seem to disrupt them.

Environmental changes-climate change in particular-have entered into the life-worlds of 'everyone', but typically as a socially constructed urgency that needs to be tackled somehow. While, until the 1990s the focus of scholarly work was on mitigation efforts [43], adaptive efforts have later gained centrality, possibly as a cue of the impossibility to mitigate climate change. What relevances climate change may have to the average person [9], they are constituted through the discursive sphere of society and may surface as eco-anxiety or social pressure to reduce one's flying, for instance. In Sweden, observers have noted that some people are ashamed of their flying and this shame has actually reduced Swedes flying [44]. Therefore, when we claim in this essay that the pragmatic sphere of everyday life is drastically decoupled from the environmental predicament, we mean that climate change, species' extinctions, and other creeping cumulative socio-material changes affect the life-worlds indirectly or these changes are virtually always mediated —not that these changes would not have any impact on the pragmatic sphere at all. The main way through which climate change and other environmental predicaments_as well as even the coronavirus_enter pragmatically into the typical life-worlds, is through public policies that, for instance, affect the relative prices of commodities and services, or through policies that force one to stay home.

As far as we see, there is an intellectualist view of the human causing of our environmental predicament that seems to pass largely unquestioned by natural and even by social scientists as the default position through which the human relationship to nature is conceptualized. However, it entails a pertinent anomaly, namely, that of rational or intellectually driven beings allegedly being increasingly aware, conscious and worried about the environmental situation, but who nevertheless continue to destroy the "natural" environment on which their lives and livelihoods ultimately 
lean $[10,31,38,45]$. Such an intellectualist imagery of the essence of the human relationship to nature has been traced back to Plato. According to William James, there is a historical sense, from Plato onward, that "the intelligible order ought to supersede the senses" ([46] quoted in [27] p. 194). The Cartesian epistemological philosophical heritage has furthermore stabilized the focus on human cognitive relation to the world—values, knowledge, attitudes—as the principal driver of our activities [29,38,47]. With such a paradigm at hand, it is natural to think of the human relationship to nature as a function of what modern humans think of nature, our attitude to it, which for their part depend on our values, awareness and especially knowledge in terms of the "natural" environment. Underlying the disconnect between the professed concerns about the environment, and the simultaneous continued engagement in environmentally destructive behavior, there looms a deficit model [48] according to which typical persons are assumed to be ignorant of or have a deficit in environmental scientific knowledge. Such ideal type persons are eager to acquire and accept scientific knowledge and "adapt to the changed epistemic circumstances" [48] (p. 162).

By contrast, Alfred Schütz, with significant parallels to certain modern pragmatists, Marxists, and practice theorists, has a different understanding of human action. One of the key tenets of this broad strand of thought has been that the human being is, so to speak, a socially and materially-or socio-materially-situated being. In this view people act according to what is relevant for them in particular socio-material situations, most of the time automatically and typically less than fully consciously, using their stock of knowledge at hand in its actual articulation [15,49]. In a similar vein, according to Schatzki, "the character and transformation of social life are both intrinsically and decisively rooted in the site where it takes place" [26] (p. xi). Modern practice theory see humans first and foremost as carriers of social practices, rather than isolable actors of their own [47,50].

\section{Life as Activity}

We begin from the phenomenological and pragmatist starting position that life, including human life in late modernity, in its every form, is activity and that any consciousness therein arises from such activity $[27,51]$. This is very different view from, for instance, that of ecological realism that presumes the primacy of being [7]. It can be seen as a question of the difference between a photo and a video and it is easy to judge which one comes closer to the lived reality. The roots of the emphasis on activity are deep and can plausibly be located in the Aristotelian rejection of Platonic abstract forms as the true "real" in favor of a view of all existence as actual, lived existence. Such influences can be seen later on, among others, in the work of Alfred Schütz, in which "human existence itself is referred to an existent life-world as a realm of practical activity" that, he continues, "is endowed with human significations" [15] (p. 127). Similarly, Theodore Schatzki writes that, "a basic fact of human life that is fundamental to the character of sociality and society... is that human life is, prominently, a continuum of activity" [52] (p. 32).

The social realm has, so to speak, activity-rather than thought, contemplation or even mere being - at its core in a similar way as "a living human being acts incessantly" [53] (p. 233). Hence, while not necessarily typically acknowledged as such, phenomenology can be seen to belong to that family of praxis philosophies arising out of the work of Hegel, Marx and pragmatists [21,54]. Common to these thinkers, furthermore, is the idea that practical activity is somehow patterned, structured or organized, entailing that the bulk of human activity is a "repetition of given components of social life" [26] (p. 7). Even though "no act can be performed twice in exactly the same manner" [55] (p. 1229), routine activity tends to continue until further notice [15], an idea that underlies the notion of habits, habitualization, institutions, path dependence, and institutionalization, e.g., in References [56,57]. If the present is predominantly some sort of continuation of the past, in order to understand the present, we have to understand its history; we have to understand the past activities within which the present minds have been constituted [51,57-59]. 


\subsection{Orientation to Social Reality}

While these thinkers conceptualize activity as patterned and historically contingent, they also see that most of the time daily activity is predominantly pragmatically, rather than intellectually, motivated. For Schutz "we have not a theoretical but an eminently practical interest" [15] (p. 208). In other words, "the subuniverse of the sensorily perceivable, physical world"' [49] (p. 5) "is to our natural attitude in the first place not an object of our thought but a field of domination" [15] (p. 227). "Natural attitude", for Schutz, is the mode in which the wide-awake person suspends doubt about the reality of everyday appearances. Such an attitude, which Edmund Husserl characterized as "our everyday taken-for-granted attitude whereby we implicitly and uncritically 'posit' the existence of a subject-independent world of spatio-temporal objects" [60] (pp. 396-397) is not about conscious choice, which means that it does not refer to an attitude such as that discussed by Elizabeth Shove [47], that is, consciously chosen attitude. Functioning with a natural attitude, one is primarily interested in that section of the world that is immediately connected to one's daily life, which is within one's reach [15] and one also takes the appearances of the objects of the reality one encounters to be the objects themselves. In other words, with a natural attitude, one does not consciously understand that the mind refracts everything external to it, but instead takes the appearances of objects as the reality tout court. While everyone certainly could transcend their natural attitude, such transcendence does not typically take place as long as life flows smoothly along its normal course without deeper disruptions, such as accidents, death of a close person, or a pandemic.

For Schutz, it is not just that everyone, due to her/his unique biographical history, automatically interprets external objects and activities in a unique way, but also that how important-how relevant-such objects and activities are for people varies. To Schutz, what is relevant for us varies according to "the conditions upon which our planning itself or its execution depends" [42] (p. 125). Jan Straßheim recapitulates well Schutz's concept of relevance: "it is relevance to an individual which shapes the selectivity of his experience, that is, which determines what arouses his attention, where his attention leads him and how far it leads him" [61] (p. 1418).

This description resonates with what Schatzki calls practical intelligibility, which "governs action by specifying what an actor does next in the continuous flow of activity" [26] (p. 75). What is relevant or practically intelligible is not the same as what is said to be important, which is to say that the notion of relevance is intended to capture something about the socio-material setting that goes beyond the expressed values or conscious thoughts of individuals. Note, and this can hardly be overemphasized, that there is usually a significant difference between the relevance structures of normal citizens' and scholars' life-worlds (who, both, typically function with a 'natural attitude') and this gap has been particularly clear in the environmental sciences, where scholars often prescribe how individuals and groups ought to act (to respond to the environmental predicament). There are drastic differences between different peoples' relevances that most importantly vary according to their place in the world system.

Even though everyone has a unique stock of knowledge and their own personal zones of relevance, for Schutz, the social world "is a preconstituted and preorganized world whose particular structure is the result of an historical process and is therefore different for each culture and society" [42] (p. 229). In this sense, while certainly there are individuals, still "what the individual does can be understood only by using the collectivity as a point of reference" [62] (p. 180). However, what is this collectivity? Schutz's above reference to culture and society is rather static and immaterial. Additionally, even though nation states or cultural constellations can and do have distinct features at a macro level, culture and society are, however, essentially fragmented in how they impose themselves on differentiated individual life-worlds.

Practice theorists have sought to resolve this dilemma by focusing on social practices, which is typically categorized as meso-level analytical stance. Social practice, according to Schatzki, is "a temporally unfolding and spatially dispersed nexus of doings and sayings" [63] (p. 89). For Schatzki, social practice is a sweeping concept that embraces two overall dimensions: activity and organization. 
Human activity, so to speak, hangs together in particular bundles. Practice theorists, in general, see individuals first and foremost as diverse carriers of, and as part of the mesh of, social practices. Only within such activity are they constituted as individuals $[47,50]$. Our subjective knowledge, which we use to derive meanings for phenomena, originates from our experiences in actual life situations $[15,51]$, that is, activities of various sorts. In other words, the individual relevance-or practical intelligibility [63]—which influences how people 'gear into the outer world' [15] (p. 227) is constituted as part of social practices and is therefore from the outset dependent on social reality.

\subsection{Materiality and Social Life}

Not only the collectivity or the social world, however, binds and constitutes the root momentum for activity, but also the material, biophysical surroundings in which such social interaction takes place. If social theory aims to explain phenomena related to the "natural" environment, it should be able to take materiality into account. The idea of such a 'material turn' is today closely associated with the work of Bruno Latour [64] and Donna Haraway [65], and adopted, in various versions, in diverse fields of academia (see, e.g., $[13,66,67]$ ), whereas Marx is the progenitor of the focus on "material" (Stoff) in social scientific thought [25]. It can be seen that tools, equipment or material artefacts mediate activity within social practices [68] and broader material arrangements, such as infrastructures, connect different practices [69]. According to Schatzki, arrangement theorists-the core of French intellectuals theorizing on the compositional structure of social life-take the arrangement of entities as 'the principal compositional feature of social life' [26] (p. xiii). Additionally, activities of any sort involve energy within and between living and non-living beings: social (and human) life in general always requires at least air, water and food. Later, Schatzki also theorized such materiality as "biological and physical flows [that] pass through practice-arrangement nexuses" [70] (p. 137). In essence, this is to address the materiality that Inge Røpke refers to when writing that "human society can be seen as a metabolic organism appropriating resources from the environment, transforming them for purposes useful for humans, and finally discarding them as waste" [71] (p. 2495). Materiality can never be detached from the social practices that use and transform them, and therefore materiality ought to be understood relationally [72].

For Schutz, individuals always find themselves in a biographically determined situation [15], which has two principal components: the ontological component of the situation-activity and the actual biographical state of the individual [42]. We find that the way Schutz addresses the situation and how it is constituted together by the mind and the immanent socio-material environment, provides a social scientifically meaningful way to conceive of materiality [73]. Schutz argues that we are not equally interested in all parts of our social and material environments, but our interest depends on how we experience and are able to dominate these parts of reality. Schutz conceptualizes zones of diminishing relevance that span from "that part of the world within our reach which can be immediately observed by us and also at least partially dominated by us" [42] (p. 124), to the zone in which "no possible change occurring within them would—or so we believe-influence our objective at hand" [42] (p. 125), that is, the zones of primary relevance and absolute irrelevance, respectively. For the majority of urban people, changes in the "natural" environment typically occur in the zone of absolute irrelevance, as they do not experience them directly, and having any effect on vast environmental changes is typically out of the question.

\subsection{Structural and Individual Levels}

Anthony Giddens' theoretical work on structuration [34] argues that individuals draw upon existing social structures thus reproducing them, but also renew or challenge them. However, for Giddens, structure and agency are two immanently related sides of the same coin, a view which has been criticized by, among others, Margaret Archer [74]. We argue that it is a fundamental feature of the contemporary system that there is a decoupling, even non-identity [31], between the structural and agential levels, in terms of the typical individual. Such a mediation is nothing new in social 
theory, as Jürgen Habermas, for instance, wrote about "the gradual uncoupling of the system from the lifeworld" [35] (p. 105). While human beings live life in the context of their particular life-worlds and with the individual relevances and practical intelligibility that this involves, environmental problems are caused and tend to occur on wholly different, much larger, temporal and geographical scales that do not (thus far, at least) impose themselves as such in immediate pragmatic terms on people's life-worlds. That is to say, environmental problems are produced by the daily operations of the global industrial market society, in the context of which the activities of geographically, temporally and culturally dispersed peoples interlink in a structure [38]. The constitution, occurrence and effects of these operations transcend the life-worlds, personal relevances, and practical intelligibility—agency—of any single individual. From such a perspective, it becomes obvious why there has not been a "storming of the Bastille" over environmental matters: for most of us, environmental issues occur in dimensions and scales whose relevance for our everyday activities seems negligible; they are intellectual issues the relevance of which is typically dwarfed by the structures of our life-world, principally the demands of getting income, as will be discussed below.

\section{Late Modern Conditions}

As we stated earlier, for Don Ihde [21] (p. 28), the concept of the life-world "combines both a genetic (historical) account and a structural one". However, the Marxist critique of phenomenological analysis argues that phenomenologists typically "fail to realize either consciousness or praxis in its historical character, and thereby fail in their attempts to give consciousness a social or non-subjective character" [59] (p. 135 emphasis in original). It is clearly not enough to merely theorize the generic, philosophical human-materiality relation; we need to understand the actual historical conditions in which humans act as carriers of social practices and within which our consciousness has been, and is being, constituted, and the real social condition of today's life-worlds [5]. This section describes schematically some of the qualitative transformations that the mesh of social practices, the life-world, and material arrangements have gone and are going through.

For one, late modernity is marked extractivism led by global corporations, increasing commodification of goods and services, and continuing virtualization that functions under the cultural and economic hegemony of the Western "developed world" [75-77]. Indeed, this acceleration [1,32,78], "a runaway development pattern", as Stoner and Melathopoulos observe, "seems foreclosed in spite of numerous attempts to change its course" [31] (p. 21).

A central, distinguishing feature of modernity—and its later phase, late modernity-is the general increase in the scale of material throughput [1]. Indeed, Hartmut Rosa defines society as modern "if it needs progressive growth, acceleration and innovation just to reproduce its social structure and to maintain its status quo" [6] (p. 3). While this typically means that ever larger machines are used in ever larger processing units that require ever larger amounts of raw material to be treated with parallel increases in consumption, such a process also provides space for niches to blossom [79]. Advances in technology have permitted and also induced this ever larger scale of economic activity, most notably perhaps the emergence and use of fossil fuels to power the increasing throughput of societal metabolism $[1,80]$. It is not only the scale of the activities, but, as Ye et al. claim, extractivism, an organized and internally coherent system for ongoing value extraction depleting distinct resource bases "has grown into a new and consistent mode of ordering large parts of our societies" [77] (p. 159).

These developments can also be associated with the growth of organizational units and bureaucracy, as Weber classically wrote in the Economy and Society [81], and larger concentrations of capital needed to induce an ever larger scale of productive activities. Today, large transnational corporations increasingly play lead in the "drama of global governance" [82] (p. 158) and working as operational centers [77] they control the global extractivist patterns of "value grabbing" [75,83]. Related to this, political decision making by the emergence of the elite "professional politician" and the political class which they come from on the one hand [84], and lobbying by special interest groups on the other (see, e.g., [85]), seem 
to have served to increase the distance between the state and its citizens. Today, the transnational capitalist class seems to have acquired state power in various parts of the world (see, e.g., [86]).

Another essential and interlinked feature of the developments in the last few decades has been the ongoing financialization [87] through which capitalist relations characterized by anonymous monetary exchanges and debt/credit relations $[88,89]$ are imposed throughout the world principally by large monopolies/oligopolies [90]. The process of financialization, in which profits, and capital in general, begin to revolve around the manipulation of financial instruments (rather than economic activities in terms of material exchanges and infrastructures) that in turn build upon or derive from other such instruments (we speak of derivatives), has been intensifying since the 1970s $[24,90]$. Financialization entails that "capital circulation flows increasingly through assets from which value is appropriated by means of dispossession and rent extraction rather than through the productive circuits of expanded capital valorization" [83] (p. 29).

After the crash of 2008, financialization gained pace through the massive bailouts which "would see the four biggest central banks pump the equivalent of $\$ 15$ trillion in new money into the global financial system" [3]. This money is-as all money is—created in the central banks and in the commercial banks in the form of credit [24,91], out of thin air, so to say. It is difficult to overemphasize the role that debt has played in the history of inequality due to the compound interest rates, which makes the debtor pay more than it has received $[89,92]$, often so much that it cannot ever pay back the debt $[24,76]$. Even though it can be argued that the world has been shrinking due to globalization, due to the ever longer global super-supply chains, such a development has in fact induced an increasing distance in the system, that is, a deeper "separation between production and consumption decisions" [88] (p. 799). The ever-increasing scale of human activity and the parallel incorporation of an increasing number of people into one system makes possible a drastic differentiation of the human population in various respects and this, indeed, has been occurring-not least in economic terms [93,94].

Certainly, this is nothing new; Marx wrote of estranged labor that "delineates the modern unfree reality where one cannot execute labor as an end in itself but rather labor functions as a process of loss of reality, impoverishment, dehumanization, and atomization" [25] (p. 32). Actually, not much of this is at all new. The structures of the system, that is, center-periphery(-hinterland) complex consistent with the accumulation of wealth, rivalry between the hegemons, as well as the main driver of the system-capital accumulation-have all been there at least several millennia, according to Frank and Gills [95] and an increasing number of other scholars [96]. Differently put, the endless and exponential "cumulation of accumulation" has only reached a scale that it no longer fits within the material boundaries of the world system without significantly altering it [78]. As the materiality of the planet cannot anymore absorb the build-up or drain that the human world system requires to function, it changes accordingly.

\subsection{The Individual Within the Mesh}

Now, as Schutz might have put it, the above schematic view of the late modern world describes that of the "disinterested observer", the social scientist attempting to understand the system. Schutz argues that the social scientist has distinct relevance structures from "interested parties", that is, people living within the system with their urges, hopes and fears [15]. Therefore, we would do well to ask how late modernity appears to, and imposes itself upon, the normal citizen, because it is the activities of the different and differentiated carriers of social practices that, by harnessing the forces of the "nature" with the help of a massive amount of technology, after all constitutes the operation of the world system.

Let us look at some qualitative transformations of the different life-worlds as they reflect the parallel developments in the wider social mesh of late modernity, that is, what these historical developments could mean in terms of activity, knowledge and zones of relevance of differentiated carriers of social practices. To use Schutz's terms [15] (pp. 53, 227), how do we "find our bearings" and "gear into the outer world" in late modernity? Potentially, even though for each individual late modernity means 
radically different things depending on their place in it, there are some systemic characteristics that can be generalized.

As Marx analyzed, part and parcel of modernization is that most of us no longer produce our own material subsistence or well-being [25], as it were, out on the field, but rather purchase the already grown, harvested, perhaps even pre-cooked corn, wheat, or rice-or slaughtered chickens, pigs or cows. We purchase our food as commodities brought to us via chains of actions-or value chains, as economists call them - that themselves have been split into linked-up commodified processes. The super-supply chains of various types of commodities require a vast logistical infrastructure and a range of supporting activities (standardization, administration, control, etc.)—typically dubbed "services". The current, increasingly specialized system makes people dependent on the systemic exchanges with anonymized others mediated by monetary, bureaucratic, and typically, digitalized relations.

It is not only that the earlier known people and known relations have been substituted by-increasingly unequal-anonymous relations, but also that, in general terms, people are more dependent in absolute terms due to the obsolescence of skills related to the acquisition of food, clothing and housing, that is, their basic needs-which again they have to buy with money. Today, people have another source of dependency: digital technologies, which they increasingly need to lean on in order to operate in everyday life [2]. In this sense, while ecological modernization, and the technologization of life it involves, has become something of a default position by which modern society engages with environmental challenges, arguably such modernization deepens the disconnect from the "natural" environment and thus, ultimately, our environmental predicament.

\subsection{Relevance of Work and "Nature"}

According to Schutz, we have a practical interest in the world, "caused by the necessity of complying with the basic requirements of our life" [15] (p. 227). Along with commodification and de-skilling, people typically have to rely on money in order to fulfill such "basic requirements" of life. In the urban life-worlds of late modernity, increasingly such money comes from salaried work or wage labor, even though the above characterized conditions obligate "to invent forms of labor and income radically heterogeneous with respect to the ones epitomized by the 'Fordist' labor norm and standard" [75]. Even if Marx understood labor as the chief mediator of social existence [13], environmental social scientific concern on work has only recently begun to focus on work. According to Lahikainen and Toivanen, "work is still one of the main sites of subject formation", which they see as "bad news for the possibilities of environmental agency" [12] (p. 16). The livelihoods of some people depend on, for example, destroying (even if only indirectly or as a side-effect) the natural habitat of species.

Environmental attitudes and issues such as consumerism are often linked with voluntary activism and seen as separate from our working lives. However, we argue that it is crucial to turn our attention to the kernel of the contemporary life-world-incomegetting - which presupposes life outside work as well as structures and delimits activities at all levels of the economy. In so far as money has paramount importance in solving nearly any type of pragmatic problem in our life-world, it is sought-regardless of the cost. The underlying issue is the extent to which people are prepared to defend their source of income, whatever it is, regardless of its environmental or other harmful impacts. Beyond the basic necessities, the marketing industry makes sure that there are ever-increasing numbers of objects of desire to purchase. The essential point here is not whether contemporary jobs are useless or not [97], but that the historical political pathway - dominated by neoliberal policies, that lean on neoclassical economics with, for instance, its "non-accelerating inflation rate of unemployment" (NAIRU) [98] that de facto legitimizes unemployment - maintains scarcity of jobs so that people have to fight for them [99]. Automatization entailing mechanization, robotization, digitalization, and so on, just means that some work gets done better and cheaper than people can ever aspire to do. There is nothing new in this pattern and John Maynard Keynes maybe most prominently saw the possibility of radically reducing the amount of work people have to do to secure their material well-being [100]. 


\subsection{The Individual and the "Natural" Environment Today}

From an environmental perspective, our actions, linked up with countless other activities in the commodified chain of production, distribution, and consumption, cause an immense environmental impact $[1,29,38]$. These are activities that lie predominantly outside our control. However, these impact are not inherently relevant to the urban life-worlds as these impacts occur at various points of the chain that we do not encounter in our primary zones of relevance: the various extraction, distribution, and discarding activities are typically not relevant parts of our life-worlds. Even though people do increasingly separate their waste, they rarely see their ultimate disposal in landfills, oceans, or the atmosphere (through incineration).

The processes of commodification and technologization of human activity have led people all over the world to adopt - to varying extents—-technological devices as a part of their everyday life with which they "gear into" reality [101]. The technologization of human action makes it hard to engage in forms of action that do not have environmental impacts: we would, in the industrialized world, find it hard to give birth to a baby without relying on an extensive healthcare infrastructure that presupposes massive healthcare industries, energy systems, educational structures and so on, to give just one example. Giving birth naturally so that one would not depend upon healthcare institutions meets not only material, but also social barriers, such as national laws and regulations.

It is not only that a thick layer of machines and other people-our linkages are socially as well as technologically mediated $[2,21,31]$ — separates us and the "natural" environment, but also that the virtualization of life-worlds makes people "likely to become still less connected with the real world" [102], which is where environmental changes actually take place. In place of face-to-face situations, we increasingly "gear into the outer world" [15] (p. 227) through our technological devices, such as laptops and smartphones, and people also increasingly "gear into" other realities-into virtual realms [101]. While the direct corporeal experience is increasingly that of perceiving audio-visual material, tapping and sitting, the actual content of experience within these virtual worlds can be nearly anything and has induced new types of social relations [103]. The virtualization of life-worlds is likely to have important implications in connection with our relationship to the "natural" environment, but more research is needed to explore this. What seems evident, though, is that due to virtualization-in a similar vein to technologization and commodification-the "natural" environment has moved downwards in the hierarchy of Schutz's zones of relevance [42] making it less and less important, especially in the direct experience of urban populations.

To recapitulate, many aspects of late modernity have increased anonymity and distance in our socio-material relations in a way that, both, other people (due to inequality and ever longer supply chains) and our "natural" environment (due to urbanization and virtualization) appear as increasingly strange- as the Other-to our life-worlds. The "natural" environment becomes known to us chiefly and often entirely through media, instead of through our direct experience and engagement within. Within such real socio-material conditions, the "natural attitude", the ubiquitous mode in which humans gear into their everyday life, has a tendency to reduce the importance of the "natural" environment in people's pragmatically driven everyday activity. It is futile "to counteract the nature-as-other paradigm" by postulating, as Jason Robert (in his otherwise truly insightful paper) and other philosophers do, that humans are "integral parts of, rather than as separate from, their environments" [27] (p. 200). That environment is the "built" environment and it is increasingly decoupled from the "natural" environment at the direct experiential level, and this separation is being chiefly done through labor relations, thus, in the last instance, through the organization of incomegetting [13].

While the "natural" environment enters as an intellectual issue into the typical urban life-world of people in the Global North, we have to understand that the prospects of such a predominantly intellectual—ethical or moral—issue to triumph over formidable structural and pragmatic pressures imposed on us, particularly in terms of our increasingly uncertain income sources, are slim (see Reference [5] for a penetrating discussion of "nonideal" theory). In addition, it might be that the risks one associates with climate change [36] are dwarfed by the risks associated with job insecurity due to 
climate change policies, which might even evoke denial and support for denialism towards climate change. What direct experiences urban people have with their "natural" environment is increasingly a leisure time and non-livelihood related issue that, even if important to many, tend not to be de facto as important as securing one's income: "Insofar as the wage continues to mediate social existence, so too, it follows, does it continue to mediate our relation to the world" [13] (p. 51).

\section{Discussion and Conclusions}

This paper has attempted to synthesize some thoughts of Alfred Schütz, Theodore Schatzki, and other like-minded theorists, apply them to the current environmental predicament and contribute to the emerging environmental social theory focusing on work [11-14] by conceptualizing incomegetting - everyday practices of getting income-as the chief structurer of the life-world. To be a chief structurer the life-world means not only that activities of getting income form the bulk of the everyday, but also that other activities of life presuppose it. People are carriers of manifold practices, at work and outside work [69], but for instance consumption practices presuppose money, and how people get money is typically from waged work. Other practices, above all rent-seeking, lending and speculative activities [24,83], inherited capital [94], are increasingly sources of one's money in the contemporary financialized and ever more unequal and unsustainable world.

It is exactly the everyday activity of the geographically and culturally radically dispersed peoples that, in an ongoing fashion, constitutes the running of the contemporary global industrial market machine, above all through our activity as laborers, producers, distributors, sellers, clerks, creditors, servers, farmers, politicians, analysts, capitalists, researchers, managers, planners, and administrators. It should go without saying that these different "small cogs" have drastically different roles, freedoms and powers in terms of the ever more extractive $[77,83]$ integrative practices into which they have been socialized [56] and as a part of which they act daily. While the elites are typically relatively free to choose their roles in the practices that constitute the global capitalist system, others are coerced into and trapped in them [104], and this is largely due to the amount of wealth they possess and are able to derive from their activities. Statistics show that global environmental changes are by and large caused by the high-consuming high-income minority in different countries [105], and it is difficult to overemphasize the drastic difference between distinct social strata in the maintenance of the system which we see taking place through various types of conspicuous consumption and pecuniary emulation [106].

While nothing dramatically novel, such a picture of reality presents some issues to be debated. As we see it, the main issue is how the core of the life-world is structured in our societies and how this core in the current, highly virtualized and commodified meshes of practices is about acquiring and securing a monetary income with which everything and anything else can be acquired. We refer to this aspect of the modern condition as the "incomegetting obligation". The concept of incomegetting is analogous to and replaces, we argue, Harriet Friedmann's concept of foodgetting, which she implies has been a major structurer of human activity for millennia [107]. Friedmann sees foodgetting as "the dimension of human history that links us directly and indirectly with all other beings" [107] (p. 245). Even though foodgetting at the system or aggregate level remains a pertinent dimension, at the individual level it is typically not the imminent aim. Instead, since food among other commodities is acquired with money, it is that which is directly procured. In other words, the structures of societies impose themselves on the small life-worlds in that money becomes not only essential, but indispensable to living a decent life, also with regard to food.

However, as argued above, since the productive system employs fewer and fewer workers per produced unit due to automatization and other advances in technology, we witness an increasing competition between workers, even though in terms of material well-being, sufficient amounts of products and services could be produced with a fraction of the people involved. The situation in which public policies (reluctantly) resuscitate the job markets so that they are able to employ even if employers would not need more employees, has been described by David Graeber adequately: “It's as 
if someone were out there making up pointless jobs just for the sake of keeping us all working" [97]. As Allan Schnaiberg already argued a long time ago, our economies can be seen as treadmills of production referring to an economy that needs to be running ever faster so that, for instance, everyone gets their jobs-and associated income. This is because most of the investments in production are in nature labor reducing investments in technologies [108]. Today, the problem has shifted further so that only a fraction of the massive quantitative easing schemes end up in productive investments while the bulk of such trillions goes into inflating asset values [24], therefore enriching the already rich.

Against such contemporary conditions, in which money is indispensable for living and its sources are artificially created through public policies that are less and less efficient and environmentally destructive, universal basic income schemes are groundbreaking. Juliana Uhuru Bidadanure defines universal basic income "as a radical policy proposal of a monthly cash grant given to all members of a community without means test, regardless of personal desert, with no strings attached and, under most proposals, at a sufficiently high level to enable a life free from economic insecurity" [28] (p. 482). The radicality of such a scheme derives from emancipating people from-desperately-reaching out for ever scarcer (decent and meaningful) jobs. With the security of incomegetting provided, people would be able to choose their jobs or at least would have the freedom to not to choose just any job for the sake of income.

Despite the criticism raised against the intellectualist and voluntarist concept of the human being as an environmentally conscious being, universal basic income could open up opportunities for environmental education and learning in something like a voluntarist fashion. The idea is, with more time and freedom in hand, direct engagement with the rhythms of the "natural" world as they can be still observed, for example, when tending a garden plot or wandering in nature at different times of the season, could once again bring these aspects within people's sphere of relevance [102]. Interest in further training and information on these aspects, as well as reskilling in farming and other such activities aiming to resuscitate at least some level of autonomy at the local levels with regard to the basic necessities, could result. Universal basic income schemes have surfaced in the global media with the coronavirus crises [109-113], as the policies to restrain the virus have induced a massive wave of unemployment and millions have lost their source of income. The situation could not be much better to implement ambitious schemes with which happiness seems to increase [109] and with the help of which, "a society with more idleness, rest, and peace and less busyness, work, administered desires, and after 'false needs'" [23] (p. 1581) could be formed.

Universal basic income would most probably yield a massive relief to the environmental burden because no more investments in production for creating jobs would have to be made with the absence of the electorate demanding for them [16]. In other words, universal basic income schemes would likely eliminate pointless jobs, and those contributing to the environmental predicament. An evident objection to such schemes from mainstream economists is that such an economic system just does not work [28]: where to get money for such policies? The simple answer is: from where it always comes from-banks. More particularly, such money to finance universal basic income would come from the central banks that have demonstrated in the financial crisis and the current coronavirus pandemic that-much - money can be created without hyperinflating currencies. Such money creation out of nothing is not magic, but theoretically well-founded practices of money management $[91,92,114,115]$ and empirically a rather well-proven issue. Universal basic income would create space for people to strive for what would be meaningful for them and, it appears, living in the rural areas and closer to "nature" could be one pertinent issue for many. At least in Finland, the place of birth of the authors of this paper, this seems to be clear as nearly one fifth of the population would like to move to the countryside, but typically cannot because of livelihoods, according to a recent survey [116].

There seems to be a "widespread helplessness that comes at the close of the twentieth century regarding the capacity of society to self-consciously transform itself" [45] (p. viii). The current coronavirus pandemic, however, demonstrates that radical political decisions can be made that effectively disrupt the treadmill and associated pollution-even if just partially and temporarily. 
Environmental predicament in its totality is, nevertheless, a whole different issue than the event-like pandemic. While the underlying aim of the "pandemic policies" is to return to normality, transitioning towards sustainability is a question about changing that normality [10,17]. It is about redesigning socio-material structures that organize the everyday activities of the people. Crucially, these structures go beyond the national borders, the broadest level of such structure being the world system with its social, economic and natural conditions [95]. Without addressing the global structures that are in their current configuration extracting and transferring wealth effectively away from the Global South $[76,77,83]$, little can be achieved in terms of global justice, as the decolonialization scholars have shown [117].

Designing a sustainable and just world is principally a struggle to organize and mobilize change in our everyday lives in the Global North, and in such a struggle we would better have our assumptions of human essence and the focus correct. As we have argued, Alfred Schütz's social phenomenology provides adequate foundations for such assumptions, and incomegetting appears to be the decisive point in this struggle. Furthermore, universal basic income schemes ought to be one of the most pertinent solutions for the current era of central bank capitalism tied with "bullshit jobs" [97]. Justifying, designing, and implementing such schemes, however, require understanding money differently than the current economics orthodoxy does. Understanding the essence of fiat-money—debt as the shadow of money-is needed when analyzing practices of incomegetting and possibilities of universal basic income schemes also with regard to sustainability transitions.

Author Contributions: Individual contributions are equal in this paper. “Conceptualization, O.I.O. and V.P.J.A.; writing-original draft preparation, O.I.O. and V.P.J.A.; writing-review and editing, O.I.O. and V.P.J.A. All authors have read and agreed to the published version of the manuscript.

Funding: This research received no external funding.

Acknowledgments: An earlier version of this essay was presented in the 3rd ISA Forum of Sociology, July 10-14, 2016, in Vienna, Austria. We would like to thank two anonymous reviewers of this journal for their comments on this essay, and for Ryan Gunderson who encouraged to submit this manuscript in this journal. All the opinions expressed and mistakes are the authors's.

Conflicts of Interest: The authors declare no conflicts of interest.

\section{References}

1. Krausmann, F.; Lauk, C.; Haas, W.; Wiedenhofer, D. From resource extraction to outflows of wastes and emissions: The socioeconomic metabolism of the global economy, 1900-2015. Glob. Environ. Chang. 2018, 52, 131-140. [CrossRef] [PubMed]

2. Couldry, N.; Hepp, A. The Mediated Construction of Reality; John Wiley \& Sons: Hoboken, NJ, USA, 2018; ISBN -13 978-0-7456-8653-0.

3. Roos, J. Ten Years on, the Crisis of Global Capitalism Never Really Ended. 2018. Available online: https://roarmag.org/essays/lehman-brothers-fallout-financial-crisis/ (accessed on 13 May 2020).

4. Mills, C.W. “Ideal theory" as ideology. Hypatia 2005, 20, 165-184.

5. Gunderson, R. A defense of the "Grand Hotel Abyss" The Frankfurt School's nonideal theory. Acta Sociol. 2015, 58, 25-38. [CrossRef]

6. Schiermer, B. Acceleration and Resonance: An Interview with Hartmut Rosa. E-Special: Four Generations of Critical Theory in Acta Sociologica. 2018. Available online: https://journals.sagepub.com/pb-assets/ cmscontent/ASJ/Acceleration_and_Resonance.pdf (accessed on 13 May 2020).

7. Ruuska, T.; Heikkurinen, P.; Wilén, K. Domination, Power, Supremacy: Confronting Anthropolitics with Ecological Realism. Sustainability 2020, 12, 2617. [CrossRef]

8. Havrancsik, D. Toward a General Theory of Understanding. Schutzian Theory as Proto-hermeneutics. Hum. Stud. 2018, 41, 333-369. [CrossRef]

9. Gunderson, R.; Stuart, D.; Houser, M. A political-economic theory of relevance: Explaining climate change inaction. J. Theory Soc. Behav. 2020, 50, 42-63. [CrossRef]

10. Ollinaho, O.I. Environmental destruction as (objectively) uneventful and (subjectively) irrelevant. Environ. Sociol. 2016, 2, 53-63. [CrossRef] 
11. Clark, B.; Foster, J.B.; Longo, S.B. Metabolic Rifts and the Ecological Crisis. In The Oxford Handbook of Karl Marx; Vidal, M., Smith, T., Rotta, T., Prew, P., Eds.; Oxford University Press: Oxford, UK, 2019; pp. 650-658. ISBN 978-0-19-069554-5.

12. Lahikainen, L.; Toivanen, T. Working the Biosphere: Towards an Environmental Philosophy of Work. Environ. Philos. 2019, 16, 359-378. [CrossRef]

13. Rekret, P. The Head, the Hand, and Matter: New Materialism and the Politics of Knowledge. Theory Cult. Soc. 2018, 35, 49-72. [CrossRef]

14. Roberts, M.J. Twilight of work: The labor question in Nietzsche and Marx. Crit. Sociol. 2016, 45, $267-280$. [CrossRef]

15. Schutz, A. Collected Papers I. The Problem of Social Reality; Martinus Nijhoff: The Hague, The Netherlands, 1962; ISBN -13 978-90-247-3046-9.

16. Klitgaard, K. Heterodox Political Economy and the Degrowth Perspective. Sustainability 2013, 5, $276-297$. [CrossRef]

17. Rudel, T.K.; Roberts, J.T.; Carmin, J. Political economy of the environment. Annu. Rev. Sociol. 2011, 37, 221-238. [CrossRef]

18. Clark, B.; York, R. Carbon metabolism: Global capitalism, climate change, and the biospheric rift. Theory Soc. 2005, 34, 391-428. [CrossRef]

19. Marx, K. Capital: A Critique of Political Economy; Vintage: New York, NY, USA, 1887; Volume I.

20. Marx, K. Grundrisse: Foundations of the Critique of Political Economy; Penguin: London, UK, 1973; ISBN 978-0-14-119403-5.

21. Ihde, D. Technology and the Lifeworld: From Garden to Earth; Indiana University Press: Bloomington, IN, USA, 1990; ISBN 9780585104751.

22. Foster, J.B.; Holleman, H. Weber and the environment: Classical foundations for a postexemptionalist sociology. Am. J. Sociol. 2012, 117, 1625-1673. [CrossRef]

23. Gunderson, R. Degrowth and other quiescent futures: Pioneering proponents of an idler society. J. Clean. Prod. 2018, 198, 1574-1582. [CrossRef]

24. Hudson, M. Killing the Host: How Financial Parasites and Debt Bondage Destroy the Global Economy; Counterpunch Books: Petrolia, CA, USA, 2015; ISBN -13 978-0-9897637-5-2.

25. Saito, K. Karl Marx's Ecosocialism; Monthly Review Press: New York, NY, USA, 2017; ISBN 978-1-58367-641-7.

26. Schatzki, T.R. The Site of the Social: A Philosophical Account of the Constitution of Social Life and Change; Penn State Press: University Park, PA, USA, 2002; ISBN 0-271-02144-6.

27. Robert, J.S. Wild Ontology: Elaborating Environmental Pragmatism. Ethics Environ. 2000, 5, $191-209$. [CrossRef]

28. Bidadanure, J.U. The Political Theory of Universal Basic Income. Annu. Rev. Polit. Sci. 2019, 22, 481-501. [CrossRef]

29. Dickson, B. The ethicist conception of environmental problems. Environ. Values 2000, 9, 127-152. [CrossRef]

30. Hukkinen, J.I. Addressing the practical and ethical issues of nudging in environmental policy. Environ. Values 2016, 25, 329-351. [CrossRef]

31. Stoner, A.M. Sociobiophysicality and the necessity of critical theory: Moving beyond prevailing conceptions of environmental sociology in the USA. Crit. Sociol. 2014, 40, 621-642. [CrossRef]

32. Gardiner, M.E. Critique of accelerationism. Theory Cult. Soc. 2017, 34, 29-52. [CrossRef]

33. Bourdieu, P. The Logic of Practice; Stanford University Press: Redwood City, CA, USA, 1990; ISBN -13 9780804720113.

34. Giddens, A. The Constitution of Society: Outline of the Theory of Structuration; University of California Press: Berkeley, CA, USA, 1984; ISBN 0-7456-0006-9.

35. Joas, H. The unhappy marriage of hermeneutics and functionalism. In Communicative Action: Essays on Jürgen Habermas's The Theory of Communicative Action; Honneth, A., Joas, H., Eds.; The MIT Press: Cambridge, MA, USA, 1991; pp. 97-118. ISBN 0-262-08196-2.

36. Beck, U. Climate for change, or how to create a green modernity? Theory Cult. Soc. 2010, 27, $254-266$. [CrossRef]

37. Cote, M.; Nightingale, A.J. Resilience thinking meets social theory: Situating social change in socio-ecological systems (SES) research. Prog. Hum. Geogr. 2012, 36, 475-489. [CrossRef] 
38. Arponen, V.P.J. A Critique of an Epistemic Intellectual Culture: Cartesianism, Normativism and Modern Crises: A Critique of an Epistemic Intellectual Culture. J. Theory Soc. Behav. 2016, 46, 84-103. [CrossRef]

39. Young, O.R.; Berkhout, F.; Gallopin, G.C.; Janssen, M.A.; Ostrom, E.; van der Leeuw, S. The globalization of socio-ecological systems: An agenda for scientific research. Glob. Environ. Chang. 2006, 16, 304-316. [CrossRef]

40. Chaffin, B.C.; Gunderson, L.H. Emergence, institutionalization and renewal: Rhythms of adaptive governance in complex social-ecological systems. J. Environ. Manag. 2016, 165, 81-87. [CrossRef]

41. Koontz, T.M.; Gupta, D.; Mudliar, P.; Ranjan, P. Adaptive institutions in social-ecological systems governance: A synthesis framework. Environ. Sci. Policy 2015, 53, 139-151. [CrossRef]

42. Schutz, A. Collected Papers II: Studies in Social Theory; Martinus Nijhoff: The Hague, The Netherlands, 1964; ISBN -13 978-94-010-1342-0.

43. Schipper, E.L. Conceptual history of adaptation in the UNFCCC process. Rev. Eur. Community Int. Environ. Law 2006, 15, 82-92. [CrossRef]

44. Mkono, M. Eco-anxiety and the flight shaming movement: Implications for tourism. J. Tour. Futures 2020. ahead-of-print. [CrossRef]

45. Stoner, A.M.; Melathopoulos, A. Freedom in the Anthropocene: Twentieth-century Helplessness in the Face of Climate Change; Springer: Berlin/Heidelberg, Germany, 2015; ISBN 978-1-137-50388-6.

46. James, W. Some Problems of Philosophy; Bison Books: Lincoln, NE, USA, 1911; ISBN 0803275870.

47. Shove, E. Beyond the ABC: Climate change policy and theories of social change. Environ. Plan. A 2010, 42, 1273-1285. [CrossRef]

48. Maranta, A.; Guggenheim, M.; Gisler, P.; Pohl, C. The reality of experts and the imagined lay person. Acta Sociol. 2003, 46, 150-165. [CrossRef]

49. Schutz, A.; Luckmann, T. The Structures of the Life-world; Northwestern University Press: Evanston, IL, USA, 1973; Volume 1, ISBN 0-8101-0622-1.

50. Reckwitz, A. Toward a theory of social practices: A development in culturalist theorizing. Eur. J. Soc. Theory 2002, 5, 243-263. [CrossRef]

51. Leontyev, A. Activity and consciousness. In Philosophy in the USSR: Problems of Dialectical Materialism; Progress Publishers: Moscow, Russia, 1977; pp. 180-202.

52. Schatzki, T. The edge of change: On the emergence, persistence and dissolution of practices. In Sustainable Practices: Social Theory and Climate Change; Shove, E., Spurling, N., Eds.; Routledge: London, UK, 2013; pp. 31-46. ISBN 9781138847156.

53. Kivinen, O.; Piiroinen, T. On the limits of a realist conception of knowledge: A pragmatist critique of Archerian realism. Sociol. Rev. 2006, 54, 224-241. [CrossRef]

54. Bernstein, R. Praxis and Action: Contemporary Philosophies of Human Activity; University of Pennsylvania Press: Philadelphia, PA, USA, 1971; ISBN 0-8122-1016-6.

55. Meyer, R.E.; Höllerer, M.A. Does institutional theory need redirecting? J. Manag. Stud. 2014, 51, 1221-1233. [CrossRef]

56. Berger, P.L.; Luckmann, T. The Social Construction of Reality: A Treatise in the Sociology of Knowledge; Penguin Books: New York, NY, USA, 1966; ISBN 9780385058988.

57. Camic, C. The matter of habit. Am. J. Sociol. 1986, 91, 1039-1087. [CrossRef]

58. Mészáros, I. The Necessity of Social Control; NYU Press: New York, NY, USA, 2014; ISBN 978-1-58367-539-7.

59. Wartofsky, M. Consciousness, praxis, and reality: Marxism vs. Phenomenology. In Interdisciplinary Phenomenology; Ihde, D., Zaner, R.M., Eds.; Martinus Nijhoff: The Hague, The Netherlands, 1977; pp. $133-151$.

60. Pollard, C. What is Original in Merleau-Ponty's View of the Phenomenological Reduction? Hum. Stud. 2018, 41, 395-413. [CrossRef]

61. Straßsheim, J. Relevance theories of communication: Alfred Schutz in dialogue with Sperber and Wilson. J. Pragmat. 2010, 42, 1412-1441. [CrossRef]

62. Hughes, E.C. The ecological aspect of institutions. Am. Sociol. Rev. 1936, 1, 180-189. [CrossRef]

63. Schatzki, T.R. Social Practices: A Wittgensteinian Approach to Human Activity and the Social; Cambridge University Press: Cambridge, UK, 1996; ISBN 0-521-56022-5.

64. Latour, B. We Have Never Been Modern; Harvard University Press: Cambridge, MA, USA, 2012; ISBN 0-674-94838-6. 
65. Haraway, D. Simians, Cyborgs, and Women: The Reinvention of Nature; Routledge: London, UK, 2013; ISBN 0-415-90387-4.

66. Pellizzoni, L. Catching up with things? Environmental sociology and the material turn in social theory. Environ. Sociol. 2016, 2, 312-321. [CrossRef]

67. Paleček, M.; Risjord, M. Relativism and the ontological turn within anthropology. Philos. Soc. Sci. 2013, 43, 3-23. [CrossRef]

68. Miettinen, R.; Paavola, S.; Pohjola, P. From habituality to change: Contribution of activity theory and pragmatism to practice theories. J. Theory Soc. Behav. 2012, 42, 345-360. [CrossRef]

69. Shove, E.; Watson, M.; Spurling, N. Conceptualizing connections: Energy demand, infrastructures and social practices. Eur. J. Soc. Theory 2015, 18, 274-287. [CrossRef]

70. Schatzki, T.R. Materiality and social life. Nat. Cult. 2010, 5, 123-149. [CrossRef]

71. Røpke, I. Theories of practice-New inspiration for ecological economic studies on consumption. Ecol. Econ. 2009, 68, 2490-2497. [CrossRef]

72. Emirbayer, M. Manifesto for a relational sociology. Am. J. Sociol. 1997, 103, 281-317. [CrossRef]

73. Van Koppen, C.S.A. (Kris) Incorporating nature in environmental sociology: A critique of Bhaskar and Latour, and a proposal. Environ. Sociol. 2017, 3, 173-185. [CrossRef]

74. Archer, M.S. Realist Social Theory: The Morphogenetic Approach; Cambridge University Press: Cambridge, UK, 1995; ISBN 0-521-48176-7.

75. Gago, V.; Mezzadra, S. A Critique of the Extractive Operations of Capital: Toward an Expanded Concept of Extractivism. Rethink. Marx. 2017, 29, 574-591. [CrossRef]

76. Hickel, J. The Divide: A Brief Guide to Global Inequality and its Solutions; Cornerstone Digital: London, UK, 2017; ISBN 978-1-4735-3927-3.

77. Ye, J.; van der Ploeg, J.D.; Schneider, S.; Shanin, T. The incursions of extractivism: Moving from dispersed places to global capitalism. J. Peasant Stud. 2020, 47, 155-183. [CrossRef]

78. Steffen, W.; Rockström, J.; Richardson, K.; Lenton, T.M.; Folke, C.; Liverman, D.; Summerhayes, C.P.; Barnosky, A.D.; Cornell, S.E.; Crucifix, M.; et al. Trajectories of the Earth System in the Anthropocene. Proc. Natl. Acad. Sci. USA 2018, 115, 8252-8259. [CrossRef]

79. Tsing, A. Beyond economic and ecological standardisation. Aust. J. Anthropol. 2009, 20, 347-368. [CrossRef]

80. Sieferle, R.P. The Subterranean Forest: Energy Systems and the Industrial Revolution; White Horse Press: Cambridge, UK, 2001; ISBN 1-874267-47-2.

81. Weber, M. Economy and Society: An Outline of Interpretive Sociology; University of California Press: Berkeley, CA, USA, 1978; Volume 1.

82. Bartley, T. Transnational corporations and global governance. Annu. Rev. Sociol. 2018, 44, 145-165. [CrossRef]

83. Andreucci, D.; García-Lamarca, M.; Wedekind, J.; Swyngedouw, E. "Value Grabbing": A Political Ecology of Rent. Capital. Nat. Soc. 2017, 28, 28-47. [CrossRef]

84. Hartmann, M. The Sociology of Elites; Routledge: London, UK, 2006; ISBN 9780203966242.

85. Klüver, H. Lobbying in the European Union: Interest Groups, Lobbying Coalitions, and Policy Change; Oxford University Press: Oxford, UK, 2013; ISBN 978-0199657445.

86. Harris, J. China's road from socialism to global capitalism. Third World Q. 2018, 39, 1711-1726. [CrossRef]

87. Lapavitsas, C. The financialization of capitalism: 'Profiting without producing'. City 2013, 17, $792-805$. [CrossRef]

88. Clapp, J. Financialization, distance and global food politics. J. Peasant Stud. 2014, 41, 797-814. [CrossRef]

89. Gerber, J.-F. The role of rural indebtedness in the evolution of capitalism. J. Peasant Stud. 2014, 41, 729-747. [CrossRef]

90. Foster, J.B.; McChesney, R.W. The Endless Crisis: How Monopoly-finance Capital Produces Stagnation and Upheaval from the USA to China; NYU Press: New York, NY, USA, 2012; ISBN 9781583673140.

91. Mitchell, W.; Wray, L.R.; Watts, M. Macroeconomics; Red Globe Press: London, UK, 2019; ISBN 978-1-137-61067-6.

92. Graeber, D. Debt: The First 5000 Years; Melville House Publishing: Brooklyn, NY, USA, 2011; ISBN 978-1-933633-86-2.

93. Hickel, J. Is global inequality getting better or worse? A critique of the World Bank's convergence narrative. Third World Q. 2017, 38, 2208-2222. [CrossRef]

94. Piketty, T. About capital in the twenty-first century. Am. Econ. Rev. 2015, 105, 48-53. [CrossRef] 
95. Frank, A.G.; Gills, B.K. (Eds.) The World System: Five Hundred Years or Five Thousand? Routledge: London, UK, 1993; ISBN 0-415-07678-1.

96. Denemark, R.A.; Friedman, J.; Gills, B.K.; Modelski, G. (Eds.) World System History: The Social Science of Long-Term Change, 1st ed.; Routledge: London, UK, 2002; ISBN 978-0-203-46770-1.

97. Graeber, D. Bullshit Jobs: A Theory; Simon \& Schuster: New York, NY, USA, 2018; ISBN 978-1-5011-4331-1.

98. Galbraith, J.K. Time to Ditch the NAIRU. J. Econ. Perspect. 1997, 11, 93-108. [CrossRef]

99. Rifkin, J. The End of Work: The Decline of the Global Labor Force and the Dawn of the Post-Market Era.; Jeremy P. Tarcher/Putnam Book: New York, NY, USA, 1995; ISBN 0-87477-779-8.

100. Kallis, G.; Kostakis, V.; Lange, S.; Muraca, B.; Paulson, S.; Schmelzer, M. Research on Degrowth. Annu. Rev. Environ. Resour. 2018, 43, 291-316. [CrossRef]

101. Ollinaho, O.I. Virtualization of the life-world. Hum. Stud. 2018, 41, 193-209. [CrossRef]

102. Monbiot, G. Our Greatest Peril? Screening Ourselves off from Reality. The Guardian. 28 February 2017. Available online: https:/www.theguardian.com/commentisfree/2017/feb/28/greatest-peril-screening-reality4chan-pewdiepie-nothing-matters-fascism (accessed on 13 May 2020).

103. Zhao, S. Constitution of mutual knowledge in telecopresence: Updating Schutz's phenomenological theory of the lifeworld. J. Creat. Commun. 2015, 10, 105-127. [CrossRef]

104. Bales, K. Blood and Earth: Modern Slavery, Ecocide, and the Secret to Saving the World; Spiegel \& Grau: New York, NY, USA, 2016; ISBN 9780812995770.

105. Ulvila, M.; Wilén, C. Engaging with the Plutocene: Moving towards degrowth and post-capitalist futures. In Sustainability and Peaceful Coexistence for the Anthropocene; Heikkurinen, P., Ed.; Transnational Law and Governance; Routledge: London, UK; New York, NY, USA, 2017; pp. 119-139. ISBN 978-1-138-63427-5.

106. Veblen, T. The Theory of the Leisure Class; Oxford University Press: Oxford, UK, 2007; ISBN 978-0-19-280684-0.

107. Friedmann, H. Towards a Natural History of Foodgetting: Natural History of Foodgetting. Sociol. Rural. 2017, 57, 245-264. [CrossRef]

108. Schnaiberg, A. The Environment: From Surplus to Scarcity; Oxford University Press: Oxford, UK, 1980; ISBN 0-19-502610-1.

109. Eskonen, H. Final Verdict on Finland's Basic Income Trial: More Happiness but Little Employment Effect; Finn. Broadcast. Co. YLE: Helsinki, Finland, 2020.

110. Henley, J. Finnish Basic Income Pilot Improved Wellbeing, Study Finds. The Guardian. 7 May 2020. Available online: https:/www.theguardian.com/society/2020/may/07/finnish-basic-income-pilot-improved-wellbeingstudy-finds-coronavirus (accessed on 13 May 2020).

111. Meredith, S. The Coronavirus Crisis Could Pave the Way to Universal Basic Income. CNBC. 6 April 2020. Available online: https://www.cnbc.com/2020/04/16/coronavirus-crisis-could-pave-the-way-to-a-universalbasic-income.html (accessed on 13 May 2020).

112. Rodriguez Martines, M. Universal Basic Income: Will It Become a Reality after Lockdown is Lifted. Euronews. 17 April 2020. Available online: https://www.euronews.com/2020/04/17/universal-basic-incomewill-it-become-a-reality-after-lockdown-is-lifted (accessed on 13 May 2020).

113. Standing, G. Coronavirus Has Shown Us Why We Urgently Need to Make a Basic Income a Reality; Glob. Agenda; World Economic Forum: Geneva, Switzerland, 2020; Available online: https://www.weforum.org/agenda/ 2020/04/coronavirus-made-basic-income-vital/ (accessed on 13 May 2020).

114. Lee, F. A History of Heterodox Economics: Challenging the Mainstream in the Twentieth Century; Routledge: Abingdon, UK, 2009; ISBN 978-0-415-77714-8.

115. Davidson, P. Financial Markets, Money and the Real World; Edward Elgar: Cheltenham, UK, 2002; ISBN 1-84064-740-X.

116. Vainio, A. Lähes Miljoona Suomalaista Miettii Vakavasti Maallemuuttoa-Yrittäjistäkin Lähes Kolmasosa. Maaseudun Tulevaisuus Politics. 16 December 2019. Available online: https://www.maaseuduntulevaisuus. fi/politiikka/artikkeli-1.764349 (accessed on 13 May 2020).

117. Mignolo, W.; Walsh, C.E. On Decoloniality: Concepts, Analytics, Praxis; Duke University Press: Durham, UK, 2018; ISBN 978-0-8223-7177-9.

(C) 2020 by the authors. Licensee MDPI, Basel, Switzerland. This article is an open access article distributed under the terms and conditions of the Creative Commons Attribution (CC BY) license (http://creativecommons.org/licenses/by/4.0/). 